\title{
Pericelis cata Marcus and Marcus, 1968 (Platyhelminthes: Polycladida): First record from northeast of Brazil
}

\author{
Vinicius Queiroz ${ }^{1 *}$, Licia Sales ${ }^{2}$, Elizabeth G. Neves ${ }^{3}$ and Rodrigo Johnsson ${ }^{3}$ \\ 1 Universidade de São Paulo, Instituto de Biociências, Departamento de Fisiologia, \\ Rua do Matão, Travessa 14, n 101, Cidade Universitária. CEP 40170-290. São Paulo, SP, Brasil. \\ 2 Universidade de São Paulo, Instituto de Biociências, Departamento de Zoologia, Rua do Matão, Travessa 14, n 101, Cidade Universitária. CEP \\ 40170-290. São Paulo, SP, Brasil. \\ 3 Universidade Federal da Bahia, Instituto de Biologia, Departamento de Zoologia. Avenida Adhemar de Barros s/nº, Campus Ondina. CEP 40170- \\ 290. Salvador, BA, Brasil. \\ * Corresponding author: E-mail: vinicius_ufba@yahoo.com.br
}

\begin{abstract}
The polyclad Pericelis cata has been reported in two distinct localities along the North Atlantic: Curaçao and the Caribbean coast of Colombia. Recently identified from the Southwestern Atlantic, the species was first described from the Cabo Frio region $\left(23^{\circ} \mathrm{S}\right.$ ) (Rio de Janeiro State), a transitional zone between warm and cold water species located southeastern Brazil. The second location is in the northeastern coast in warm waters, in the entrance of the Todos-os-Santos Bay, a geographic area within the Brazilian Biotic Province, an important center of marine biodiversity of the Tropical Atlantic.
\end{abstract}

Records of marine invertebrates from Tropical Southwestern Atlantic have been known since 17th Century (Marcgrave 1942; Amaral and Jablonski 2005). However, after four centuries, the knowledge on species diversity, particularly small free-living flatworms, remains largely incipient.

Contrasted with the subtropical and temperate environments of the Southern coast of Brazil $\left(34^{\circ} \mathrm{S}-\right.$ $22^{\circ} \mathrm{S}$ ), the northeastern coast is typically characterized by the occurrence of highly productive and diverse tropical ecosystems including coral reefs and mangroves. According to Spalding et al. (2007), it is part of the Tropical Southwestern Atlantic also comprising the Brazilian Biotic Province (Briggs 1974). Extending southward from the Orinoco River $\left(2^{\circ} \mathrm{S}\right)$ to Cabo Frio $\left(23^{\circ} \mathrm{S}\right)$, the Brazilian Province is a remarkable center of biodiversity with a high proportion of Caribbean fauna and endemic species from very distinct taxa. Following the latitudinal diversity gradient (Hillebrand 2004), the region of Cabo Frio (northern Rio de Janeiro State) has been interpreted as a transitional zone between tropical and temperate water species (Floeter and Soares-Gomes 1999).

In marine environments, commonly associated with benthic communities, living on or under rocks and corals, free living polycladid flatworms play an important ecological role as food source for predatory fish and nudibranchs, and also have a beneficial role for scleractinian corals by removing biological wastes from the polyps and also preying on sessile organisms (Schockaert 1996, Rawlinson and Litvaitis 2008). Around 20,000 species of flatworms have been estimated to live associated with reef corals (Stella et al. 2011). In fact, a corallivorous species has been recently described from the Great Barrier Reef (Rawlinson and Stella 2012).

Reefs and coral communities are widespread in warm waters of the Todos-os-Santos Bay (TSB) and seashore of the Salvador city $\left(12^{\circ} \mathrm{S}-13^{\circ} \mathrm{S}\right.$, Bahia State)
(Leão 1996, Leão et al. 2003), however the biodiversity of benthic fauna have been largely underestimated. The great contribution of E. Marcus and E. du Bois-Reymond Marcus in the 50's and 60's resulted in the description of approximately 66 species of polycladids, most localities of which were restricted to the colder waters of Northern and southeastern littoral region of São Paulo State (Marcus 1946; 1947; 1948; 1949; 1950; 1951; 1952; 1954; Marcus and Marcus 1968). Despite the expected species richness along the northeastern littoral area, the inventory of polycladids associated with coral communities in this area have so far comprised only two species from Southern Bahia State $\left(16^{\circ}\right.$ S) (Armatoplana leptalea (Marcus, 1947), Stylochoplana walsergia Marcus and Marcus 1968).

After four decades, studies developed by Bahia and Padula (2009) and Bahia et al. (2012) have provided a new scenario on the species richness of Brazilian polycladids. Two species - Pseudoceros bicolor Verrill, 1901 and Pericelis cata Marcus and Marcus, 1968, have been reported from Northern Rio de Janeiro to the region of Cabo Frio $\left(23^{\circ} \mathrm{S}\right)$, and another five - Enchiridium evelinae Marcus, 1949, Phrikoceros mopsus (Marcus, 1952), Pseudobiceros evelinae (Marcus, 1950), Thysanozoon brocchii (Risso, 1818) and Hoploplana divae Marcus, 1950, have been identified from coastal reefs of the Rio Grande do Norte State $\left(5^{\circ} S-6^{\circ} S\right)$, on the northeastern coast.

Intending to contribute to the knowledge of the geographical distribution patterns of the Brazilian polycladids, the present study establishes the occurrence of Pericelis cata in the lower latitude of the Bahia State. Following the work of Bahia and Padula (2009), the occurrence of the species is now extended northward (from $23^{\circ} \mathrm{S}$ to $13^{\circ} \mathrm{S}$ ). Therefore, the new finding adds to the inventory of the free-living polycladids from the northeastern coast, and to the biodiversity of the Brazilian Biotic Province as well.

Sampling was carried out during low tide by snorkeling 
in the Barra beach $\left(13^{\circ} 00^{\prime} 37^{\prime \prime} \mathrm{S} 38^{\circ} 31^{\prime} 49^{\prime \prime} \mathrm{W}\right)$, located next of the entrance of the TSB (12 $\left.{ }^{\circ} 40^{\prime} \mathrm{S} 13^{\circ} 10^{\prime} \mathrm{S}\right)$, on February 2011 and January 2012 (Figure 1B). Two specimens were found under rocks in reef pools (Figure 2) at 1-2 $\mathrm{m}$ depth. In the laboratory they were photographed with a digital camera NIKON COOLPIX 995 attached to a NIKON SMZ1000 stereomicroscope supplied with a calibrated eyepiece and examined for identification. Based on morphological characters, including color pattern, marginal, tentacular and cerebral eyes and tentacles, the species was diagnosed according to Marcus and Marcus (1968). Following Newman and Cannon (2003), the material was fixed in frozen $10 \%$ formalin in seawater and preserved in $70 \%$ ethanol. Voucher specimens were deposited in the Platyhelminthes Collection of the 'Museu de Zoologia da Universidade Federal da Bahia' (acronym: UFBA 001 (40.0 mm), UFBA 017 (32.4 mm)).

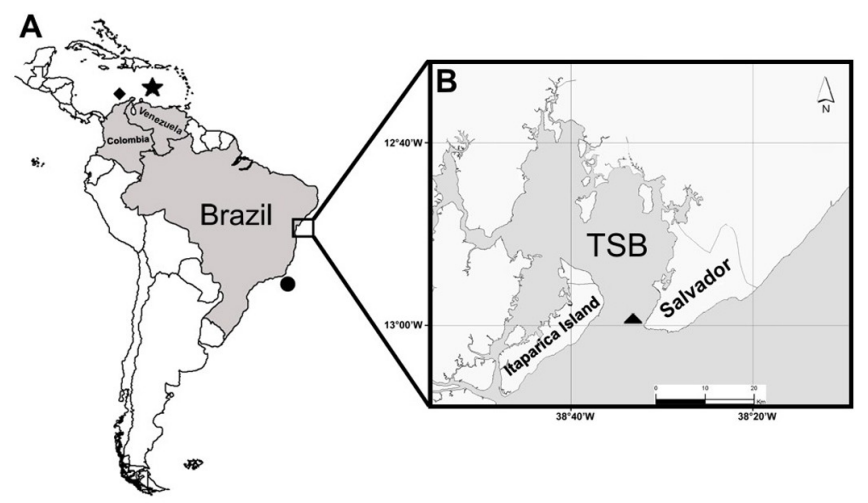

FIgURE 1. Geographic distribution of Pericelis cata. A - South America and Caribbean sea. B - Todos-os-Santos bay in detail. Star = Curaçao, Type locality (Marcus and Marcus 1968); diamond = Caribbean coast of Colombia (Quiroga et al. 2004b); circle = Cabo frio, Rio de Janeiro - Brazil (Bahia and Padula 2009); triangle = present record, Salvador Bahia Brazil; TSB - Todos-os-Santos Bay.

Order Polycladida Lang, 1884

Suborder Cotylea Lang, 1884

Superfamily Pseudocerotoidea Faubel, 1984

Family Pericelidae Laidlaw, 1902

Pericelis cata Marcus and Marcus, 1968 (Figures 2 and 3AE)

Type locality: Curaçao, Caribbean Sea, North Atlantic

Description:Flattenedand delicatespecieswith relaxed body form usually oval-shaped and commonly reaching 40 mm length (Figures 2, 3A and B). Crumpled marginal folds sticking together (Figures 3A, B and D). Dorsal background creamy, with black spots and brown patches randomly distributed (Figures 3A, C and D). Background also creamy ventrally, except for the branched digestive trait and the reproductive structures that are whitish, differing considerably to the opposite surface (Figure 3B). Pharynx sometimes visible through the translucent body (Figure 3B) with numerous folds, and measuring about $14.5 \mathrm{~mm}$ (Figure 3B), hence $44.5 \%$ of the body length. Tentacles formed by marginal folds of the margin and with $4 \mathrm{~mm}$ between each one (Figure 3D). Cerebral eyes centrally and anteriorly displaced considering the anterior-posterior axis, just after the tentacles (Figure 3D). Cerebral eyes consisting of two groups of black spots not well separated medially and containing 45 - 55 eyes each cluster. The eyes

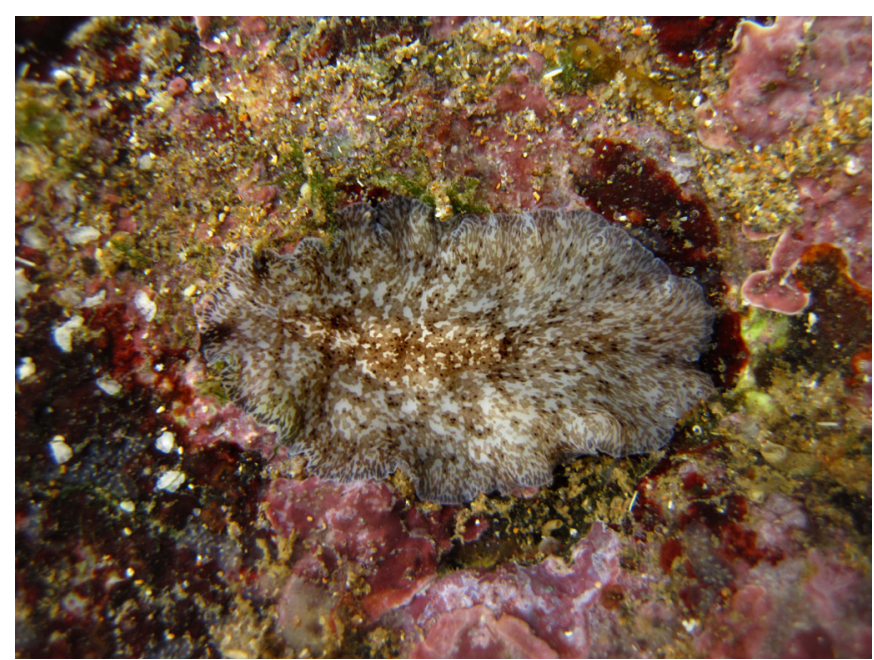

Figure 2. In situ photograph of Pericelis cata found under rocks at the Barra beach.

measuring between 35 and $38 \mu \mathrm{m}$ (Figure 3E). Tentacular eyes densely grouped in the margin of tentacle and close to anterior edge (Figure 3D). Marginal eyes surround the entire body and not showing apparent pattern. Sucker, male and female gonopores located in the posterior region (final 1/3). Gonopores too close to sucker and situated $1 \mathrm{~mm}$ ahead of it.

The specimens observed in this study agree completely with the original description (Marcus and Marcus 1968) and additional works (Quiroga et al. 2004a, b; Bahia and Padula 2009).

Considering the previous pattern of geographical distribution, it is possible to observe a large gap between the occurrence areas (Figure 1A). Firstly described from the Tropical Northwestern Atlantic Province (Curaçao - Marcus and Marcus 1968, Colombia - Quiroga et al.

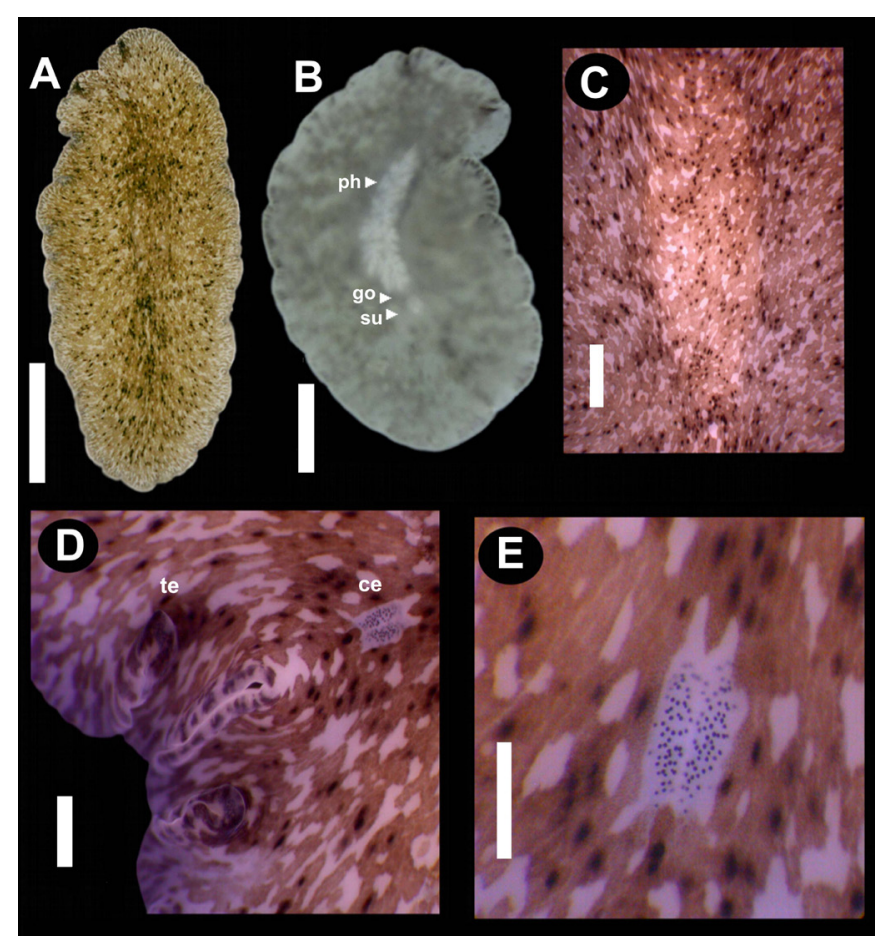

FIgurE 3. Plate of Pericelis cata. A - Dorsal view of alive animal; B Ventral view showing the digestive system; $\mathrm{C}$ - Digestive system in dorsal view; D - Anterior region of P. cata; E - Cerebral eyes in detail showing eyes (black spots). Sacales: $\mathrm{A}=10 \mathrm{~mm}$; $\mathrm{B}=7 \mathrm{~mm}$; $\mathrm{C}=2.5 \mathrm{~mm}$; D =1.5 $\mathrm{mm}$; E = $1 \mathrm{~mm}$. ce, cerebral eyes; go, gonopores; ph, pharynx; su, sucker, te, tentacles. 
2004a), Pericelis cata was reported in the colder waters of Southern Brazil (Bahia and Padula 2009), in a transitional region between the Tropical Southwestern Atlantic and the Warm Temperate Southwestern Atlantic Province (Spalding et al. 2007), the limit of which is defined by the thermodynamic features of the coastal upwelling area of Cabo Frio, Northern Rio de Janeiro (Ekman 1953, Briggs 1974). In fact, the species is apparently adapted to very distinct environments with eurithermic characteristics.

However, extending northward along the Brazilian coast, the new record from Bahia State (in Tropical Southwestern Atlantic Province), reinforces the range extension of Pericelis cata to the Tropical Atlantic Realm (Spalding et al. 2007). Thus, it is likely that further collection efforts may highlight other areas of occurrence of $P$. cata indicating a wider geographic distribution of this species along the northeastern coast (and the Brazilian Biotic Province).

Zoogeographically, diverse taxa as mollusks, crustaceans and corals of fauna assemblages of the Brazilian northeastern region are similar, in constitution, to those of the Caribbean (Palacio 1980, Neves et al. 2006, Neves et al. 2008, Neves et al. 2010, Spalding et al. 2007, Floeter et al. 2008, Queiroz et al. 2011, Sales et al. 2011). Similarly, the co-occurrence of polycladid species in Brazilian and Caribbean waters have been largely pointed out in the literature - e.g., Phaenocelis medvedica Marcus, 1952; Phrikoceros mopsus (Marcus, 1952); Prosthiostomum gilvumm Marcus, 1950; Pseudoceros bicolor Verril, 1902; Thysanozoon brochii (Risso, 1818) and Pericelis cata Marcus and Marcus, 1968 (Quiroga et al. 2004b; Carbayo and Froehlich 2008; Bahia and Padula 2009; Bahia et al. 2012). Nevertheless, among reported Southwestern Atlantic polycladids, a total of 42 species remain exclusively endemic to Brazil, and thus restricted to the Southwestern Atlantic (Marcus 1947; 1948; 1949; 1950; 1952; 1954; Corrêa 1958; Marcus and Marcus 1968; Bahia and Padula, 2009).

\section{Literature Cited}

Amaral, A.C.Z. and S. Jablonski. 2005. Conservação da biodiversidade marinha e costeira no Brasil. Megadiversidade 1(1): 43-51.

Bahia, J. and V. Padula. 2009. First record of Pseudoceros bicolor and Pericelis cata (Platyhelminthes: Polycladida) from Brazil. Marine Biodiversity Records, 1-5.

Bahia, J., V. Padula and M. Delgado. 2012. Five new records and morphological data of polyclad species (Platyhelminthes: Turbellaria) from Rio Grande do Norte, Northeastern Brazil. Zootaxa 3170: 31-44.

Briggs, J.C. 1974. Marine Zoogeography. New York: McGraw-Hill (Publishers). $475 \mathrm{p}$.

Carbayo, F. and E.M. Froehlich. 2008. Estado do conhecimento dos macroturbelários (Platyhelminthes) do Brasil. Biota Neotropica 8(4): 177-197.

Corrêa, D.D. 1958. A new polyclad from Brazil. Boletim do Instituto oceanográfico de São Paulo 7:81-86.

Ekman, S. 1953. Zoogeography of the Sea. London: Sidgwick \& Jackson (Publishers). $417 \mathrm{p}$.

Floeter, S.R. and Soares-Gomes, A. 1999. Biogeographic and species richness patterns of Gastropoda on the Southwestern Atlantic. Revista Brasileira de Biologia 59(4): 567-575.

Floeter, S.R., L.A. Rocha, D.R. Robertson, J.C. Joyeux, W.F. Smith-Vaniz, P. Wirtz, A.J. Edwards, J.P. Barreiros, C.E.L. Ferreira, J.L. Gasparini, A. Brito, J.M. Falcón, B.W. Bowen and G. Bernardi. 2008. Atlantic reef fish biogeography and evolution. Journal of Biogeography 35: 22-47.
Hilldebrand, H. 2004. On the Generality of the Latitudinal Diversity Gradient. The American Naturalist 163(2): 192 - 211.

Leão, Z.M.A.N. 1996. The coral reefs of Bahia: morphology, distribution and the major environmental impacts. Anais da Academia Brasileira de Ciências 68(3): 439-452.

Leão, Z.M.A.N., R.K.P. Kikuchi and V. Testa. 2003. Corals and Coral Reefs of Brazil. In J. Cortês. (ed.) Latin America Coral Reefs. Amsterdam: Elsevier Publisher.

Marcgrave, J. 1942. História natural do Brasil. São Paulo: Museu Paulista da Universidade de São Paulo.

Marcus E. 1947. Turbellários marinhos do Brasil. Boletim da faculdade de filosofia ciências e letras de São Paulo Zoologia 12:93-215.

Marcus E. 1948. Turbellaria do Brasil. Boletim da faculdade de filosofia ciências eletras de São Paulo, Zoologia 13: 111-243.

Marcus E. 1949. Turbellaria Brasileiros (7). Boletim da faculdade de filosofia ciências e letras de São Paulo Zoologia 14:7-155.

Marcus E. 1950. Turbellaria Brasileiros (8). Boletim da faculdade de filosofia ciências e letras de São Paulo Zoologia 15:5-192.

Marcus E. 1952. Turbellaria Brasileiros (10). Boletim da faculdade de filosofia ciências e letras de São Paulo Zoologia 17:5-188.

Marcus E. 1954. Turbellaria Brasileiros (11). Papeis avulsos do departamento de Zoologia. Secretaria da agricultura 11:419-489.

Marcus, E. and E. Marcus. 1968. Polycladida from Curação and faunistically related regions. Studies on the Fauna of Curação and other regions 26:1-106.

Neves, E.G., F.L. Silveira, M. Pichon, and R. Johnsson. 2010. Cnidaria, Scleractinia, Siderastreidae, Siderastrea siderea (Ellis and Solander, 1786): Hartt Expedition and the first record of a Caribbean siderastreid in tropical Southwestern Atlantic. Check List 6: 505-510.

Neves, E.G., R. Johnsson, C.L.S. Sampaio and M. Pichon. 2006. The occurrence of Scolymia cubensis in Brazil: revising the problem of the Caribbean solitary mussids. Zootaxa 1366: 45-54.

Neves, E.G., S.C. Andrade, F.L. Silveira and V.N. Solferini. 2008. Genetic variation and population structuring in two brooding coral species (Siderastrea stellata and Siderastrea radians) from Brazil. Genetica (The Hague) 132: 243-254.

Newman, L.J. and L.R.G. Cannon. 2003. Marine flatworms: the world of polyclads. Collingwood: CSIRO. $97 \mathrm{p}$.

Palacio, F.J. 1980, Revisión zoogeográfica marina del sur del Brasil. Boletim do Instituto oceanográfico de São Paulo 31(1): 69-92.

Queiroz, V.A., L.O. Sales, E.G. Neves and R. Johnsson, R. 2011. Dissodactylus crinitichelis Moreira, 1901 and Leodia sexiesperforata (Leske, 1778): first record of this symbiosis in Brazil. Nauplius 19: 63-70.

Quiroga S.Y., D.M. Bolanõs and M.K. Litvaitis. 2004a. A checklist of polyclad flatworms (Platyhelminthes: Polycladida) from the Caribbean coast of Colombia, South America. Zootaxa 633: 1-12.

Quiroga S.Y., D.M. Bolanõs and M.K. Litvaitis. 2004b. Policládidos (Platyhelminthes: "Turbellaria") del Atlático Tropical Ocidental. Biota Colombiana 5: 159-172.

Rawlinson, K.A. and Litvaitis, M.K. 2008. Cotylea (Polycladida): a cladistic analysis of morphology. Invertebrate Biology 127(2): 121-138.

Rawlinson, K.A. and Stella, J.S. 2012. Discovery of the Corallivorous Polyclad Flatworm, Amakusaplana acroporae, on the Great Barrier Reef, Australia - the First Report from the Wild. PLoS ONE 7(8): e42240.

Sales, L., M. Delgado, V. Queiroz, V. Padula, C.L.S. Sampaio and R. Johnsson. 2011. First record of Flabellina dana Millen and Hamann, 2006 (Mollusca: Nudibranchia) in the South Atlantic Ocean. Check List $7(6): 880-882$

Schockaert, E.R. 1996. The importance of turbellarians in ecosystems. In G.S. Hall (ed.) Methods for the examination of organismal diversity in soils and sediments. Wallingford: Cabi Publishing.

Spalding M.D., H.E. Fox, G.R. Allen, N. Davidson, Z.A. Ferdaña, M. Finlayson, B.S. Halpern, M.A. Jorge, A. Lombana, S.A. Lourie, K.D. Martin, E. McManus, J. Molnar, C.A. Recchia and J. Robertson. 2007. Marine ecoregions of the world: a bioregionalization of coastal and shelf areas. BioScience 57: 573-583.

Stella, J.S., M.S. Pratchett, P.A. Hutchings and G.P. Jones. 2011. CoralAssociated Invertebrates: Diversity, Ecological Importance and Vulnerability to Disturbance. Oceanography and Marine Biology: An Annual Review 49: 43-104.

RECEIVED: August 2012

ACCEPTED: March 2013

PUBLISHED ONLINE: June 2013

EDITORIAL RESPONSIBILITY: Luis E. Arruda Bezerra 